\title{
Santral Tiroid Hormon Direnci Saptanan Olgularda Tiroid Hormon Reseptör Gen Analizi ve Periferik Direnç Eşliğinin Araştırılması
}

\author{
Investigation of the Concomittant Peripheral Resistance and \\ Thyroid Hormone Receptor Gene Analysis in Cases With Central \\ Thyroid Hormone Resistance

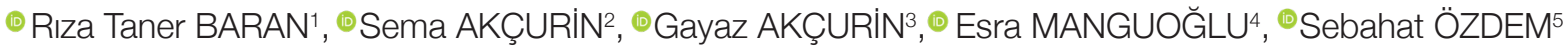

\author{
${ }^{1}$ Antalya Eğitim Araștırma Hastanesi, Çocuk Endokrinoloji Bölümü, Antalya, Türkiye \\ ${ }^{2}$ Akdeniz Üniversitesi Tıp Fakültesi, Çocuk Sağlığı ve Hastalıkları Anabilim Dalı, Çocuk Endokrinoloji Bilim Dalı, Antalya, Türkiye \\ ${ }^{3}$ Antalya Medikal Park Hastanesi, Çocuk Kardiyoloji Bölümü, Antalya, Türkiye \\ ${ }^{4}$ Akdeniz Üniversitesi Tıp Fakültesi, Tıbbi Genetik Anabilim Dalı, Antalya, Türkiye \\ ${ }^{5}$ Akdeniz Üniversitesi Tıp Fakültesi, Biyokimya Anabilim Dalı, Antalya, Türkiye
}

Öz

Amaç: Hipofizer tiroid hormon (TH) direnci düşünülen ve klinik bulguların ayırdettirici olmadığı çocuk olgularda periferik direnç eşliğinin değerlendirilmesi ve TH $\beta$ reseptörü (TRß) mutasyon sıklığının belirlenmesi amaçlanmıştır.

Gereç ve Yöntemler: Hipofizer TH direnci tanısı ile izlenen ve yeterli dozda levotiroksin (L-T4) tedavisi almalarına rağmen izlem süreçlerinde tiroid stimülan hormon $(\mathrm{TSH})$ düzeyleri baskılanamayan, 20 olgu (13 kı, ort yaş $7.03 \pm 2.72$ yıl,) çalışmaya alınmıştır. TH periferik etkileri, suprafizyolojik doz levotriiodotironin (L-T3) uygulaması öncesi ve sonrası serbest T3 (sT3), serbest T4 (sT4), TSH, seks hormon bağlayıcı globulin (SHBG), total kolesterol, alkalen fosfataz (ALP), osteokalsin, anjiotensin konverting enzim (ACE) düzeyleri ve kreatin fosfokinaz (CPK), M-mod ve Doppler ekokardiyografi (EKO) tetkikleri ile değerlendirilmiş ve TRß gen analizleri yapılmıştır.

Bulgular: Olguların L-T3 öncesi ve sonrası biyokimyasal ölçütleri karşılaştırıldığında SHBG, osteokalsin, ACE düzeylerinde anlamlı artış, total kolesterol ve CPK düzeylerinde ise anlamlı ölçüde azalma olduğu gözlenmiştir ( $p<0.001)$. ALP ve kardiyak parametrelerde farklılık görülmemiştir. TRß gen analizinde, olguların ikisinde homozigot, dördünde heterozigot rs3752874 ve iki hastada homozigot, 7 hastada heterozigot IVS8 -110 G\&gt;A değişimi saptanmıştır.

Sonuç: Olgularımızda suprafizyolojik L-T3 konsantrasyonlarına değişik derecelerde periferik doku yanıının gözlenmesi, yüksek T3 düzeylerine yanıtın korunduğunun göstergesidir ve en yüksek yanıtın oluştuğu SHBG ve CPK değişimleri yol gösterici olabilir. TRß gen analizinde saptanan iki değişimin direnç patogenezinde rolü olmadığı düşünülmüştür. Yeterli tedavi kriterleri taşımalarına rağmen TSH düzeyleri ısrarlı yüksek seyreden doğumsal hipotiroid olgularda genetik bir anomali eşliğinden çok, hipotalamus-hipofiz-tiroid ekseninin intrauterin dönem olgunlaşma sürecindeki fonksiyonel bir hatanın sorumlu olduğu düşünülebilir.

Anahtar Sözcükler: Hipotiroidi, Tiroid hormon direnci

\begin{abstract}
Objective: This trial was designed to assess the concomitant peripheral resistance in pediatric cases, who were considered to have pituitary thyroid hormone (TH) resistance and exhibited indistinguishable clinical results and determine the incidence of TH $\beta$ receptor (TR $\beta$ ) mutation in the "investigational group".

Material and Methods: 20 patients, monitored with the diagnosis of pituitary TH resistance, in whom thyroid stimulating hormone (TSH) level could not be suppressed during monitoring despite an adequate dose of levothyroxine (L-T4) administered, were included in the trial (13 girls, mean age: $7.03 \pm 2.72$ years). TH peripheral effects were assessed before and after liothyronine (L-T3) administration using free T4 (FT4), TSH, sex hormone-binding globulin (SHBG), total cholesterol, alkaline fosfatase (ALP), osteocalcin, anjiotensin coverting enzyme (ACE) levels and creatine phosphokinase (CPK), M-mod and Doppler ECHO investigations and TR $\beta$ gene analyses were performed.

Results: The comparison of the pre-L-T3 and post-L-T3 biochemical measurements revealed a significant increase in SHBG, osteocalcin and ACE levels and a significant reduction in total cholesterol and CPK levels $(p<0.001)$. No
\end{abstract}


difference was detected in ALP and cardiac parameters.TR gene analysis revealed homozygote and heterozygote rs3752874 changes in 2 and 4 patients respectively, and homozygote and heterozygote IVS8 -110 G\&gt;A changes in 2 and 7 patients, respectively.

Conclusion: Achievement of various degrees of peripheral tissue response to supraphysiological L-T3 concentrations indicates that the response to high T3 levels is maintained and the SHBG and CPK changes exhibiting the highest responses may be guiding. The two changes detected in the TR $\beta$ gene analysis were considered not to be involved in the pathogenesis of resistance. In patients with congenital hypothyroidism, who sustain high levels of TSH despite meeting adequate therapeutic criteria, the condition may be attributed to a functional defect in the intrauterine growth process of the hypothalamic- pituitary-thyroid axis rather than a concomitant genetic abnormality.

Key Words: Hypothyroidism, Thyroid hormone resistance

\section{Giriș}

Tiroid hormon direnci (THD) çoğunlukla otozomal dominant olarak kalıtılan ve hedef dokuların [izole hipofizer veya jeneralize (hipofizer+periferik doku)] tiroid hormonlarına duyarlıı̆ının değişen derecelerde azalmasına yol açan bir sendromdur.Tiroid hormonunun hücre zarından taşınması, hücreiçi tiroid hormon metabolizması ve hormon aktivasyonu, nükleer reseptöre bağlanma, ko-regülatörlerle etkileşim veya post-reseptör işlem basamaklarında hata sonucu gelişen tiroid hormonuna son organ yanıtsızığı durumudur. Yüksek tiroid hormon $(\mathrm{TH})$ düzeylerine rağmen tiroid stimülan hormonun (TSH) baskılanmamış olması karakteristiktir (1).

Olguların \%90'ında, THD, tiroid hormon $\beta$ reseptörünün (THRB) iki allelinden birindeki mutasyonun sonucu gerçekleşir. THR genlerinin görece ekspresyon ve dağılımları farklılık göstermektedir. Bu durumun bireyler arası periferik direnç derecesinde farklılık ya da aynı kişinin farklı dokularında değişken direnç yaratabileceği bilinmektedir. Hastanın metabolik durumu, izole hipofizer direnç varlığında hipertiroid iken, periferik direnç eşliğinde direncin șiddetine göre ötiroid veya hipotiroid olabilir. Hasta bazında bu tanımlar genellikle sanal ölçekte kalmakta ve bu ayrımı yapmak kolay olmamaktadır. İzole hipofizer direnç görünümlü bir hastada periferik tutulum eşliği tedavi kararının en önemli belirleyicisidir. Özgün klinik bulguların olmaması, klinik hastalığın görünüm ve seyrinin değişken olması ve aynı kişide hipotiroidi ve hipertiroidi semptomlarının birarada bulunabilmesi bu kararı önemli ölçüde etkilemektedir (2-6).

Periferik TH direncinin değerlendirilmesinde olgu verilerinin sağlıklı kontrol verileri ile karşılaştırıması, hem yaş ve cins uyumlu standart değerlerin olmayışı, hem de normal değer aralıklarının çok geniş olması nedeniyle mümkün değildir. Bu nedenle bireylerarası farklılıktan çok, bireyiçi değişim, yani kişinin suprafizyolojik hormon düzeylerine verdiği doku yanıtı daha belirleyici olmaktadır $(1,7,8)$.

Bu çalışmada, tiroid hormon direnci profiline sahip olgularda kısa süreli L-T3 tedavisine belirli periferik etki ölçütlerinin değişimi değerlendirilerek klinikte yararlı olabilecek ölçüt/ ölçütlerin saptanması ve biyokimyasal ve/veya klinik THD özelliklerini taşıyan olgularda en sık görülen genetik neden olan THRB mutasyonunun taranması planlanmıştır (1,7,9-12). Türk çocuklarında ilk kez yapılan bu çalışma ile THRB mutasyon sıklığının "araştırma grubunda" belirlenmesinin yanısıra, hipofizer $\mathrm{TH}$ direnci düşünülen ve klinik bulguların ayırtettirici olmadığı çocuk olgularda periferik direnç eşliğinin değerlendirilmesi izlem ve tedavi süreçlerinde yol gösterebilecek klinik/biyokimyasal bir ölçütlerin belirlenmesi amaçlanmıştır.

\section{GEREÇ ve YÖNTEMLER}

Mayıs 2009 ile Mayıs 2011 tarihleri arasında, Pediatrik Endokrinoloji BD Polikliniğine başvuran veya bu tarihler arasında takipte olup ortalama yaş_SD'si 7.03 \pm 2.72 olan doğumsal primer hipotiroidi tanısı ile izlenen, tanı anında veya takip sırasında fizyolojik replasman dozunda LT4 tedavisi almakta iken en az 1 yıllık izlem sürecinde ortalama sT4 $\geq 1.44$ (0.93-1.7) ng/dl olup, TSH $\geq 4.2$ (0.27-4.2) ulU/ml bulunan, kronik ve sendromik bir hastalığı olmayan, konjenital kalp hastalığı bulunmayan ve Hashimoto tiroiditi tanısı dışlanmış 20 hasta (13 kız, 7 erkek) çalışmaya alındı. Çalışma için Akdeniz üniversitesi etik kurulundan onay alındı. Çalışmaya alınma kriterlerine uyan ve çalışmaya katılmayı kabul eden olgulardan imzalı bilgilendirilmiş onam formu alındı. Olguların tanı yaşları, antropometrik verileri, fizik muayene bulguları, guvatr eşliği, izlemdeki tiroid hormon düzeyleri, Tirotiropin salgılatıcı hormon $(\mathrm{TRH})$ testine $\mathrm{TSH}$ yanıtları ve ultrasonografik tiroid volümleri dosyalarından kaydedildi. Tiroid ultrasonografisinde tiroid bez volümünün yaşa göre < -2 SDS (standart sapma skoru) olması hipoplazi, > +2 SDS olması guvatr olarak kabul edildi (13).

Bu olgulardaki hipofizer tiroid hormon direncine periferik doku direnç eşliği araştırıldı. Bu amaçla tedavi almayan hastalar veya fizyolojik replasman dozunda L-T4 tedavisi almaktayken tedavisi tarafımızdan 2 ay kesilen olgularda tiroid hormonunun periferik etkilerini değerlendirmek amacıyla sT3, sT4, TSH, SHBG, kolesterol, ALP, osteokalsin, ACE ve CPK düzeyleri çalışıldı. M mod ve Doppler EKO ile kardiyak değerlendirme yapıldı. Daha sonra 10 gün boyunca $50 \mu \mathrm{g} / \mathrm{m}^{2}$ dozunda L-T3 verilerek aynı parametreler tekrarlandı ve istatistiksel olarak değerlendirildi. Artan dozlarda ardışık L-T3 verilmesi ve her bir periyodda biyokimyasal parametrelerin ve TRH'a TSH yanıtının ölçülmesi şeklinde yapılan standart uygulama ekonomik yetersizlik nedeniyle ve ayrıca çocuk hastalarda yıpratıcı bir süreç olma gerekçesiyle modifiye edildi ve suprafizyolojik doz, replasman dozunun 2.5 katı olacak biçimde ayarlandı.

TH reseptör mutasyon analizi için DNA örnekleri ayrıldı.

\section{Ekokardiyografi Kayıtları}

Tüm hastalara standart iki boyutlu ve Doppler ekokardiyografik inceleme yapıldı. Sol ventrikül çapları iki boyutlu görüntüleme kılavuzluğunda M-mode ile ölçüldü. Sol ventrikül sistol ve diyastol 
sonu volümleri ve ejeksiyon fraksiyonları apikal iki ve dört boşluk görüntülerden ölçüldü. M-mod ve iki boyutlu ekokardiyografik görüntüler ve renkli akım Doppler kayıtları 3.5 MHz probe kullanılarak GE 7 Vivid 7 Pro ekokardiyografi cihazı ile alındı. "Transmitral pulsed wave Doppler" hız kayıtları üç kardiyak siklus incelenerek yapıldı. E ve A hızları sırasıyla erken diyastolde ve atriyal kontraksiyondan sonra ulaşlan en yüksek değerler olarak tanımlandı. Doku Doppler kayıtları apikal uzun eksende mitral kapak düzeyinde lateral ve medyal segmentler, septum orta segment, sol ventrikül lateral duvarı segmentlerinden; sağ ventrikülde triküspit kapak medyal ve lateral segment ve sağ ventrikül serbest duvar segmenti alınarak yapıldı. Her segment için $E, A$ ve $S$ dalgaları ölçüldü. İzovolümetrik kontraksiyon zamanı (IVKZ), izovolümetrik relaksasyon zamanı (IVRZ) ve miyokardiyal performans indeksi (MPi) hesaplandı.

\section{Biyokimyasal Değerlendirme}

Tedavi almayan veya fizyolojik dozda replasman L-T4 tedavisi almakta iken tedavisi 2 ay tarafımızdan kesilen tüm olgularda tedavi öncesi ve 10 gün L-T3 tedavisi sonrası sT3, sT4, TSH, SHBG, kolesterol, alkalen fosfataz, osteokalsin, ACE, CPK düzeyleri çalışıldı. Olguların kanları sabah 09.00-10.00 arasında alındı. Serumları $-20^{\circ} \mathrm{C}$ 'da donduruldu ve eş zamanlı aynı araştırmacı tarafından çalışıldı.
N-Mid Osteokalsin, SHBG: serum örneklerinde Elektrokemilüminesans İmmünassay yöntemi kullanılarak Roche Modular Analytics E170 immunoassay analizöründe ölçüldü ( Roche Diagnostics GmbH, Mannheim, Germany).

ACE, FAPGG metodu kullanılarak $340 \mathrm{~nm}$ dalga boyunda kinetik kolorimetrik yöntemle ölçüldü (Ben srl Biochemical Enterprise Milano, Italy).

Serum alkalen fosfataz ve CPK düzeyleri, standardize kolorimetrik metod ile; total kolesterol, kolesterol esteraz ve kolesterol oksidaz enzimlerinin kullanıldığı enzimatik kolorimetrik metod ile Roche Cobas 8000 otoanalizöründe ölçüldü. (Roche Diagnostics $\mathrm{GmbH}$, Mannheim; Germany).

Serum sT3, sT4, TSH düzeyleri, Elektrokemilüminesans İmmünassay yöntemi kullanılarak ölçüldü (Roche Diagnostics GmbH, Mannheim; Germany). sT3 düzeyi normal aralığı 1.84.6 pg/ml, sT4 düzeyi normal aralığı 0.93-1.7 ng/dl, TSH düzeyi normal aralığı 0.27-4.2 ulU/ml olarak alındı.

\section{İstatistiksel Analiz}

Değişkenlerin normal dağlıma uygunluğunu araştırmak için Kolmogorov-Smirnov testi uygulandı. Normal dağlıma uygunluk durumunda parametrik yöntem olan "iki eş arası farkın anlamlılık testi" uygulandı. Normal dağılımdan sapma gözlendiğinde ise

Tablo I: Olguların THD tanı verileri.

\begin{tabular}{|c|c|c|c|c|c|c|}
\hline $\begin{array}{l}\text { Hasta } \\
\text { no }\end{array}$ & THD tanı yaşı (ay) & $\begin{array}{l}\text { THD izlem süresi } \\
\text { (ay) }\end{array}$ & $\begin{array}{c}\text { sT3 (N:1.8-4.6) } \\
\text { (pg/ml) }\end{array}$ & $\begin{array}{c}\text { sT4 (N:0.93-1.7) } \\
\text { (ng/dl) }\end{array}$ & $\begin{array}{c}\text { TSH (N:0.27-4.2) } \\
\text { (IU/ml) }\end{array}$ & $\begin{array}{l}\text { TRH'ya TSH yanit } \\
\text { (IU/ml) }\end{array}$ \\
\hline 1 & 39.0 & 74.64 & 5.70 & 1.58 & 9.23 & 123.3 \\
\hline 2 & 20.0 & 51.04 & 6.25 & 1.76 & 10.85 & \\
\hline 3 & 20.0 & 37.0 & 4.53 & 1.73 & 6.17 & 100.0 \\
\hline 4 & 12.0 & 141.6 & 3.80 & 1.72 & 10.46 & 64.0 \\
\hline 5 & 4.0 & 64.5 & 4.86 & 1.61 & 12.8 & \\
\hline 6 & 21.0 & 64.92 & 2.09 & 1.71 & 9.11 & \\
\hline 7 & 39.0 & 86.76 & 4.75 & 1.64 & 7.27 & 56.72 \\
\hline 8 & 23.0 & 42.0 & 4.5 & 1.47 & 5.18 & \\
\hline 9 & 20.0 & 87.5 & 3.31 & 1.49 & 14.04 & 21.99 \\
\hline 10 & 11.0 & 89.9 & 5.35 & 2.03 & 10.9 & \\
\hline 11 & 19.0 & 35.0 & 4.49 & 1.57 & 5.15 & \\
\hline 12 & 12.0 & 115.8 & 2.49 & 1.69 & 22.9 & \\
\hline 13 & 90.0 & 38.1 & 5.85 & 2.38 & 4.53 & 34.0 \\
\hline 14 & 19.0 & 20.4 & 3.55 & 1.7 & 10.26 & 29.49 \\
\hline 15 & 48.0 & 17.4 & 4.79 & 2.33 & 4.25 & 123.3 \\
\hline 16 & 26.0 & 17.6 & 3.92 & 1.54 & 21.06 & \\
\hline 17 & 50.0 & 23.8 & 5.11 & 1.48 & 7.86 & 100.0 \\
\hline 18 & 79.0 & 12.08 & 6.2 & 1.9 & 4.9 & 64.0 \\
\hline 19 & 10.0 & 35.84 & 3.67 & 1.73 & 6.16 & \\
\hline 20 & 5.0 & 64.84 & 3.66 & 1.45 & 40.38 & \\
\hline Ort $\pm S D$ & $28.57 \pm 2.37$ & $55.55 \pm 3.5$ & $4.44 \pm 1.14$ & $1.72 \pm 0.25$ & $11.17 \pm 8.54$ & $61.27 \pm 32.92$ \\
\hline
\end{tabular}


parametrik olmayan yöntem olan Wilcoxon işaret testi kullanıldı. Veriler ortalama $\pm S D$ şeklinde gösterildi. $\mathrm{P}<0.05$ düzeyi anlamllık derecesi olarak kabul edildi. Tüm analizler PASW (versiyon release 18.0.0) yazılımı ile gerçekleştirildi.

\section{BULGULAR}

Jeneralize tiroid hormon direnci tanı kriterlerini taşıyan toplam 20 olgu çalışma kapsamında değerlendirildi. 20 olgunun \%65'i kız ( $n=13), \% 35$ 'i $(n=7)$ erkekti. Çalışma sırasındaki ortalama yaşları $7.03 \pm 2.72$ yı (ortanca 6.05 yıl, yaș aralığı 3.29 - 12.08 yıl) olan hastaların retrospektif olarak dosyaları incelendiğinde 20 olgunun 9'unda tanı aşamasında TRH uyarı testi yapıldığı ve 30. dakikadaki TSH pik ortalamasının 61.27 $32.92 \mu \mathrm{lU} /$ $\mathrm{ml}$ olduğu, olguların hiçbirinde guvatr saptanmadığı, tiroid bez volümlerinin 20 olgunun 7'sinde (\%35) normal, 10'unda (\%50) hipoplazik, 3 olguda ise (\%15) agenezik olduğu görüldü. Biyokimyasal hipotiroidisi olan hastalar replasman dozunda L-T4 tedavisi alırken, 3 olgu tedavisiz olarak izlenmekteydi. Hiçbir olgu hipertiroidi belirti ve bulgularını taşımamaktaydı.

Yirmi olgunun THD olarak kabul edildikleri dönemde "ortalama izlem değerlerinin" ortalaması olarak sT3'lerinin $4.44 \pm 1.14 \mathrm{pg} /$ $\mathrm{ml}(4.51 \mathrm{pg} / \mathrm{ml}, 2.09-6.25 \mathrm{pg} / \mathrm{ml}) ;$ sT4'lerinin $1.72 \pm 0.25 \mathrm{ng} / \mathrm{dl}$ $(1.69 \mathrm{ng} / \mathrm{dl}, 1.45-2.38 \mathrm{ng} / \mathrm{dl})$ ve TSH düzeylerinin $11.17 \pm 8.54$ $\mu \mathrm{lU} / \mathrm{ml},(9.17 \mu \mathrm{lU} / \mathrm{ml}, 4.25$ - $40.38 \mu \mathrm{lU} / \mathrm{ml})$ olduğu gözlendi. Ortalama THD tanı yaşları $28.57 \pm 2.37$ ay, (20 ay, $4-90$ ay), ortalama izlem süreleri $55.55 \pm 3.5$ ay (izlem aralı̆ı̆ 12.08-115.8 ay)'dı (Tablo I).

Yirmi olgunun son kontrolde ortalama boy SDS'leri $0.38 \pm 1.2$ [0.57,(-2.1)- (+2.78)], ortalama takvim yaşı-kemik yaşı farkları (TY-KY) $-1.34 \pm 0.97$ [0, (-2)- $(+1.1)]$ bulundu. Her iki parametre arasında istatistiksel ilişki gözlenmedi.

Tedavi almayan veya fizyolojik dozda aldıkları L-T4 tedavileri 2 ay kesilen toplam 20 olgunun 10 günlük L-T3 uygulaması sonrası uykuda ve 10 dakika dinlenim ardından kalp tepe atımları sayılarak ortalamaları alındı. Tedavi öncesi $(82.85 \pm 6.91$ atım/dk) ve sonrasında (83.1 $\pm 7.12 \mathrm{atım} / \mathrm{dk})$ değerler arasında istatistiksel anlamlı bir fark bulunmadı $(p>0.05)$.

Olguların tedavisi 2 ay kesildikten sonra bakilan SHBG, osteokalsin, ACE düzeyleri, 10 gün L-T3 verildikten sonraki değerlerle karşılaştııldığında istatistiksel olarak anlamlı artış saptanmıştır $(p<0.001)$. Kolesterol ve CPK düzeylerinde ise istatistiksel olarak anlamlı azalma gözlenmiştir $(p<0.001)$. ALP düzeyleri arasında istatistiksel olarak anlamlı bir fark bulunmamıştır ( $\mathrm{p}=0.185$ ) (Tablo II).

\section{M-mod EKO sonuçları}

Tüm olguların tedavi 2 ay kesildikten ve 10 gün L-T3 tedavisi aldıktan sonra iki boyutlu ekokardiyografide sistol ve diyastol sonu interventriküler septum kalınlığı (IVSs/d), sol ventrikül sistol ve diyastol sistol sonu çapı (SVÇs/d), sol ventrikül sistol ve diyastol sonu arka duvar kalınlığı (SVADs/d), sol ventrikül diastol sonu çap (LVIDd), sol ventrikül arka duvar kalınlığı (LVPWd), intraventriküler septum sistol sonu çap (IVSs), sol ventrikül sistol sonu çap (LVIDs), sol ventrikül sistolik posterior duvar kalınlığı (LVPWs), ejeksiyon fraksiyonu (EF) ve \% kısalma fraksiyonu $(K F)$, Mitral E, A dalgaları ve mitral E/A oranı kaydedildi ve istatistiksel olarak karşılaştırıldı. İstatistiksel olarak anlamlı bir farkllik bulunmadı ( $p>0.05)$.

\section{Doppler EKO sonuçları}

Tüm olguların tedavi 2 ay kesildikten ve 10 gün L-T3 tedavisi aldıktan sonra Doppler EKO ile sol ventrikül, mitral lateral, mitral medial, interventriküler septum (IVS), triküspit medial, triküspit lateral ve sağ ventrikülden $E, A, S$ dalga ölçümleri ile izovolümetrik kontraksiyon zamanı (IVKZ), izovolümetrik relaksasyon zamanı (IVRZ) ölçüldü. Miyokardiyal performans indeksi (MPI) hesaplandı. Bu değerler kaydedilip istatistiksel olarak karşılaştııldı. İstatistiksel olarak anlamlı bir fark bulunamadı $(p>0.05)$.

\section{Moleküler Genetik Analiz Sonuçları}

Yirmi hastanın genomik DNA örneklerinin THRB genine ait 8

Tablo II: Olguların 10 günlük L-T3 tedavi önce ve sonrası biyokimyasal verileri.

\begin{tabular}{|c|c|c|c|}
\hline & Tedavi Öncesi & Tedavi sonrası & $\mathbf{P}$ \\
\hline SHBG (nmol/L) & $92.44(9.3-177.7)$ & $145.2(36.16-148.8)$ & $<0.001$ \\
\hline Kolesterol (mg/dl) & 202.5 (106-449) & $151.5(84-255)$ & $<0.001$ \\
\hline CPK (U/L) & $246.5(54-1547)$ & $106.0(51-320)$ & $<0.001$ \\
\hline Osteokalsin (ng/ml) & $57.8(29-98.1)$ & $83.76(44.5-130)$ & $<0.001$ \\
\hline ALP (U/L) & $440.9(143-747)$ & $489.3(130-664)$ & $>0.05$ \\
\hline ACE (U/L & $21.9(2.9-60.5)$ & $28.9(12.7-51.4$ & $<0.005$ \\
\hline sT3 (pg/ml) & $2.71(0.26-6.4)$ & $5.1(1.25-16.9)$ & $<0.001$ \\
\hline sT4 (ng/dl) & $1.22(0.05-2.23)$ & $0.31(0.05-1.84)$ & $<0.001$ \\
\hline TSH & $50.4(2.6-990)$ & $3.02(0.04-198.7)$ & $<0.001$ \\
\hline
\end{tabular}


ekzonik bölgenin oligonükleotid dizileri ile amplifikasyonları yapıldı. Saptanan değişimler dizi analizi ile değerlendirilerek gen bankasındaki THRB referans dizi (NG_009159.1) ile karşılaştııldı. Hastaların ikisinde (3 ve 6 nolu hastalar) tek nükleotid değişimlerinden biri olan rs3752874 homozigot

Tablo III: Olguların genotip özellikleri.

\begin{tabular}{|c|c|c|}
\hline \multirow[b]{2}{*}{ Hasta no } & \multicolumn{2}{|c|}{ Genotip } \\
\hline & $\begin{array}{c}\text { Rs3752874 } \\
\text { NG_009159.1: g.356319C>T NM_000461.4: } \\
\text { c.735C>T NP_000452.2: p.Phe245Phe }\end{array}$ & $\begin{array}{l}\text { NG_009159.1: g.356007G>A } \\
\text { NM_000461.4: c.533-110 G>A }\end{array}$ \\
\hline 1 & $\mathrm{C} / \mathrm{C}$ & $\mathrm{G} / \mathrm{G}$ \\
\hline 2 & $\mathrm{C} / \mathrm{C}$ & $\mathrm{G} / \mathrm{G}$ \\
\hline 3 & $T / T$ & A/A \\
\hline 4 & $\mathrm{C} / \mathrm{C}$ & $\mathrm{G} / \mathrm{G}$ \\
\hline 5 & $\mathrm{C} / \mathrm{T}$ & $\mathrm{G} / \mathrm{A}$ \\
\hline 6 & $T / T$ & A/A \\
\hline 7 & $\mathrm{C} / \mathrm{C}$ & $\mathrm{G} / \mathrm{G}$ \\
\hline 8 & $\mathrm{C} / \mathrm{C}$ & $\mathrm{G} / \mathrm{G}$ \\
\hline 9 & $\mathrm{C} / \mathrm{C}$ & $\mathrm{G} / \mathrm{G}$ \\
\hline 10 & $\mathrm{C} / \mathrm{T}$ & $\mathrm{G} / \mathrm{A}$ \\
\hline 11 & $\mathrm{C} / \mathrm{C}$ & $\mathrm{G} / \mathrm{G}$ \\
\hline 12 & $\mathrm{C} / \mathrm{T}$ & $\mathrm{G} / \mathrm{A}$ \\
\hline 13 & $\mathrm{C} / \mathrm{C}$ & $\mathrm{G} / \mathrm{A}$ \\
\hline 14 & $\mathrm{C} / \mathrm{C}$ & $\mathrm{G} / \mathrm{G}$ \\
\hline 15 & $\mathrm{C} / \mathrm{C}$ & $\mathrm{G} / \mathrm{G}$ \\
\hline 16 & $\mathrm{C} / \mathrm{C}$ & $\mathrm{G} / \mathrm{G}$ \\
\hline 17 & $\mathrm{C} / \mathrm{C}$ & $\mathrm{G} / \mathrm{A}$ \\
\hline 18 & $\mathrm{C} / \mathrm{C}$ & $\mathrm{G} / \mathrm{A}$ \\
\hline 19 & $\mathrm{C} / \mathrm{T}$ & $\mathrm{G} / \mathrm{A}$ \\
\hline 20 & $\mathrm{C} / \mathrm{C}$ & $\mathrm{G} / \mathrm{G}$ \\
\hline
\end{tabular}

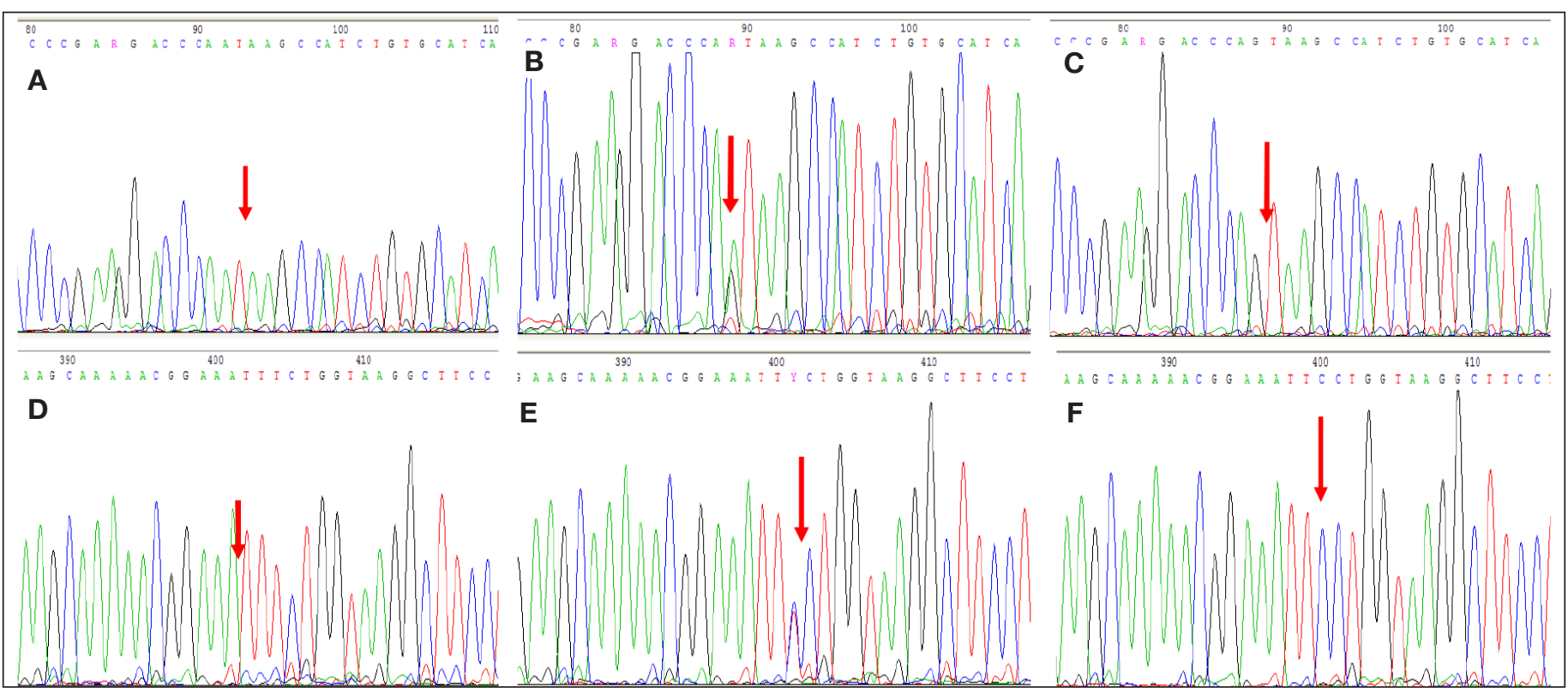

Șekil 1: Dizi analizi sonuçları: IVS8 -110 G>A değișimi için homozigot (A), heterozigot (B), normal (C) bireylere ait örnekler, rs3752874 polimorfizmi için homozigot (D), heterozigot (E), normal (F) bireye ait örnekler. 
genotip çizelgesi tablo III'de, dizi analizi sonuçları Şekil 1'de gösterilmektedir.

\section{TARTIŞMA}

THD tiroid hormonuna doku yanıtsızlığı olarak tanımlanan kalıtsal bir sendromdur. Olguların çoğu ötiroid olmakla birlikte, hafif hipotiroid veya tirotoksik de olabilirler. THRa ve THRB izoformlarının doku dağıımı, farklı dokulardaki değişken direnç nedeniyle aynı hastada hipo ve hipertiroidi bulgularının yer aldığı mozaik bir tablo yaratabilir. En sık görülen bulgular guvatr, büyüme geriliği ve hipertiroid kardiyak semptomlardır $(14,15)$.

THD olgularında guvatr eșliği \%22-90 arasında verilmektedir. Çalışmamızdaki 20 olgudan tiroid disgenezisi (hipoplazi ve agenezi) bulunmayan 7 olguda $(1,5,13,15,17,18,19$ nolu hastalar) THD tanısı aldıkları dönemde ve izlemde guvatr saptanmadı. Bu durum fenotipik değişkenlikten kaynaklanacağı gibi, izlem süresinin guvatr oluşumu için yeterli olmamasına da bağlı olabilir.

THD'nde çocukluk döneminde boy kısalığı ve KY geriliği görece \%18-25 ve \%29-47 olarak belirtilmektedir $(1,16)$. Boy SDS değerleri -2.1 ile +2.78 arasında bulunan olgularımızda TYKY farkı da -2 ile +1.1 arasında değişmekteydi. Özellikle sT4 düzeyleri iyi izlem kriteri taşıyan konjenital hipotiroidili hastalar da dahil olmak üzere, olgular boy SDS, TY-KY ve hedef boyları açısından incelendiğinde bu parametreler arasında ve bu parametrelerle TSH-TH düzeyleri arasında ilişki saptanmadı. THR izotiplerinin doku dağlımı ve duyarlığı ile ilişkili olan bu durum yine periferik direnç eșliğini değerlendirmenin ne ölçüde güç olduğuna ve bu verilerin olgu bazında bireyselleștirilerek tartışı|ması gerektiğine işaret etmektedir.

T3'ün diyastolik gevșemeyi kısaltıcı etkisi nedeniyle hipertiroidizmde kardiyak gevşeme süresi kısalırken, hipotiroid hastaların diyastol süresi uzamaktadır (17). Kardiyak tutulum daha çok erişkin THD olgularında beklenen bir bulgudur. Erken çocukluk çağında orta derecede taşikardi \%33-75 oranında bildirilmektedir. 3.5-13.7 yaşları arasında THD'li çocuklarda sağ|ıkı kontrollere göre, kalp hızının daha yüksek, sol atrium çapının daha geniş ve sol ventrikül ejeksiyon fraksiyonunun daha kısa olduğu belirtilmiştir $(18,19)$.

Kırkbir yetişkin ve 13 çocuk hastayı içeren geniş kapsamlı bir prospektif çalışmada, THD olguları 24 hipertiroid, 20 hipotiroid hasta ve 22 sağlıkı ötiroid kontrolle karşılaştııımış ve mutasyon tipi ile kardiyovasküler bulgular arasında korelasyon gözlenmemiştir. Yaş uyumlu kontrol grubu ile karşılaştıııldıklarında THD'li çocuklarda kalp hızının belirgin yüksek, sol ventrikül ejeksiyon fraksiyonunun düşük ve myokardiyum diyastolik gevşeme zamanının kısa olduğu görülmüştür. THD'li hastalarda kardiyak output, atım volümü ve sistolik aortik akış hızı belirgin düşük, diyastolik parametrelerden isovolemik relaksasyon ve yavaşlama zamanı kısa bulunmuştur. THD'de serum sT3 ile kalp hızı ve sT4 ile sol ventrikül ejeksiyon fraksiyonu arasında pozitif, sT3 ve sT4 ile isovolemik relaksasyon arasında negatif bir bir ilişki olduğu gözlenmiştir (19).

Çalışmamızda olguların ortalama kalp tepe atımları, suprafizyoljik L-T3 uygulaması öncesi ve sonrasında anlamlı farklılık göstermemiş, Doppler EKO ile verileri de anlamlı farklı bulunmamıștır. Bu durum olgularımızda kardiyak etkilenmenin olmadığı veya çocukluk yaş grubunda kardiyak tutulumun henüz ortaya çıkmadığı şeklinde yorumlanabilir.

Periferik hormon etkisinin değerlendirilmesi amacıyla parametrelerin rastgele ölçümü normal değerlerin çok geniş aralıkta yer alması nedeniyle pratik değildir. Bu nedenle suprafizyolojik L-T3 uygulama öncesi ve sonrası değerlerin karșılaștırıması daha sağlam bir ölçüt olarak kabul görmektedir. Bu nedenle olgularımızda periferik direnç eșliği veya șiddeti hakkında fikir sahibi olabilmek için suprafizyolojik dozda L-T3 ile 10 günlük tedavi uygulaması gerekmiştir. Artan dozlarda ardışוk L-T3 verilmesi ve her bir periyodda biyokimyasal parametrelerin ve TRH'a TSH yanıtının ölçülmesi şeklinde yapılan standart uygulama ekonomik yetersizlik nedeniyle ve ayrıca çocuk hastalarda yıpratıcı bir süreç olma gerekçesiyle modifiye edilmiș ve suprafizyolojik doz, replasman dozunun 2.5 katı olacak biçimde ayarlanmıșıı. THD'de normal yanıt körelmiş, kaybolmuş veya paradoks olabilir. Ancak teorik olarak normal yanıt da beklenebilir. Çünkü normal reseptörün yüksek hormon düzeylerinde artmış T3 satürasyonu direncin bir ölçüde kırımasını sağlayabilir. Ayrıca mutant reseptörün normal reseptörün fonksiyonunu ne ölçüde inhibe ettiği de yanıtı belirleyen faktörlerdendir (1).

Bazal ve artan dozlarda verilen L-T3 tedavisi sonrası SHBG düzeylerinin araştııılığı bir çalışmada, 10 jeneralize THD'li hasta ile 21 normal, 28 hipotiroid ve 20 hipertiroid olgu ile karşılaşı̧ııımış ve jeneralize THD'i olan hastaların bazal ortalama SHBG düzeylerinin hipotiroid ve kontrol grubundan farklı olmadığı; ancak hipertiroidili hasta grubundan belirgin düşük olduğu saptanmıştır (20). 50 mg, $100 \mu \mathrm{g}$ ve $200 \mu \mathrm{g}$ artan dozlarda L-T3 uygulamasından sonra normal, hipotiroid ve hipertiroid hastalarda artış gözlenirken, jeneralize THD olan hastalarda paradoksal azalma olduğu görülmüștür.

Bir başka çalışmada, 104 THD'li olgu, kontrol grubuyla karşllaştırımış ve serum kolesterol, ferritin ve SHBG düzeyleri arasında istatistiksel olarak anlamlı farkllık bulunmamıștır (18).

Refetoff ve Weiss (7), generalize THD'li 11 hastada 3 günlük artan dozlarda L- T3 uygulaması sırasında kolesterol ve CPK düzeylerinin $100 \mu \mathrm{g} / g u ̈ n ~ L-T 3$ dozunda, kontrol grubuna göre göre anlamlı yüksek, SHBG düzeyinin ise anlamlı düşük olduğunu bildirmişlerdir. 
Olgularımızda suprafizyolojik dozda L-T3 uygulamasını takiben TH periferik etki ölçütlerinin (SHBG- \%57 yüksek, osteokalsin- \%44.9 yüksek, ACE- \%28.5 yüksek, CPK- \% 57 düşük, kolesterol- \%25.2 düşük) beklenen yönde ve farklı oranlarda anlamlı ölçüde değişiklik göstermesi generalize tiroid hormon direnci (hipofizer + periferik direnç) olasılığını tümüyle dışlamamış, sadece yüksek doz L-T3 ile direncin bir ölçüde yenilebileceğine işaret etmiştir. THD olgularında TH periferik etki ölçütlerinin "standart tanı kriterleri" oluşturmaktan ve genotipfenotip uyumundan uzak olduğu açıktır.

Olgularımızda THRB geninin moleküler analizinde, iki farklı genomik değişim bulunmuştur. Bunlardan (p.Phe245Phe) değişimi, protein düzeyinde bir fark oluşturmamaktadır. Sorensen HG ve ark. (21) 52 olgu ve 1116 sağlıklı bireyde yaptıkları çalışmada, bu polimorfizm ile tiroid hormon düzeyleri arasında bağlantı olmadığı gösterilmiştir. Bu nedenle, bu polimorfizm hastalıkla ilişkilendirilmemektedir. Diğer değişim ise 8. intron bölgesindedir (IVS8-110 G>A). Bu değişim ilk defa bu çalışmada saptanmıştır. İntron bölgesinde olması nedeni ile protein düzeyindeki etkisini öngörmek için ek çalışmalara gereksinim duyulmuştur.

Sonuç olarak, yüksek tiroid hormon düzeylerine rağmen olgularda kardiyak etkilenme gözlenmemiştir. Bu durum doz artımı gerektiren olgularda klinik açıdan güvenlik sağlamakla birlikte, THR izotiplerinin değişken dağılımı ve duyarlığı göz önünde bulundurularak olguların taşikardi ve olası kardiyak tutulum yönünden izlemleri şarttır.

Periferik direnç varlığından şüphe duyulan olgularda en yüksek yanıtın oluştuğu SHBG ve CPK parametreleri yol gösterici olabilir.

Olgularımızın THRB gen analizinde saptanan iki değişimin direnç patogenezinde rolü olmadığı düşünülmüștür. Bunlardan p.Phe245Phe polimorfizminin hastalıkla ilişkili olmadığı gösterilmiştir. Diğer değişikliğin (IVS8-110G>A) intron bölgesinde yer alması patolojik etki olasılığını azaltmaktadır. Ancak kesin veri için ek çalışma gerekmektedir.

Doğumsal hipotiroid olgularda yeterli tedavi kriterleri tașımalarına rağmen gözlenen ısrarlı TSH yüksekliği dikkat çekicidir. Bu olgularda TH direncine neden olacak genetik bir hatanın eşbirlikteliği düşük olasılıktadır. Dolayısıyla klinik ve TSH yüksekliği dışında biyokimyasal olarak iyi tedavi kriteri taşıyan doğumsal hipotiroid hastalarda mevcut sorundan genetik bir anomali eşliğinden çok, hipotalamus-hipofiz-tiroid ekseninin intrauterin dönem olgunlașma sürecindeki fonksiyonel bir hatanın (pozitif-negatif geri denetim geçiş döneminde yanlış ayarlanmış eşik değeri) sorumlu olduğu düşünülebilir.

\section{Finansal Kaynak}

Bu çalışma sırasında, yapılan araștırma konusu ile ilgili doğrudan bağlantısı bulunan herhangi bir ilaç firmasından, tıbbi alet, gereç ve malzeme sağlayan ve/veya üreten bir firma veya herhangi bir ticari firmadan, çalışmanın değerlendirme sürecinde, çalışma ile ilgili verilecek kararı olumsuz etkileyebilecek maddi ve/veya manevi herhangi bir destek alınmamıştır.

\section{Çıkar Çatışması}

Bu çalışma ile ilgili olarak yazarların ve/veya aile bireylerinin çıkar çatışması potansiyeli olabilecek bilimsel ve tıbbi komite üyeliği veya üyeleri ile ilişkisi, danışmanlık, bilirkişilik, herhangi bir firmada çalışma durumu, hissedarlık ve benzer durumları yoktur.

\section{KAYNAKLAR}

1. DiLaura R, De Felice M. Resistance to Thyroid Hormone. In: Degroot LJ, Jameson JL, editors. Endocrinology. 5th ed. Philadelphia: Saunders 2006; 2227-37.

2. Akcurin S. Tiroid fonksiyonları bozuk olan çocuk. 14. Ulusal Pediatrik Endokrin ve Diabet Kongresi 4-10 Ekim 2010 Muğla; 81.

3. Refetoff S, Dumitrescu AM. Syndromes of reduced sensitivity to thyroid hormone: genetic defects in hormone receptors, cell transporters and deiodination. Best Pract Res Clin Endocrinol Metabol 2007;21:277-305

4. Takeda K, Sakurai A, DeGroot LJ, Refetoff S. Five new families with resistance to thyroid hormone not caused by complete deletion of the protein coding region of the thyroid hormone receptor beta gene. J Clin Endocrinol Metab 1992;74:49- 55.

5. Ono S, Swartz ID, Mueller OT, Root AW, Usala SJ, Bercu BB. Homozygosity for a dominant negative thyroid hormone receptor gene responsible for generalized resistance to thyroid hormone. J Clin Endocrinol Metab 1991;73:990-4.

6. Weiss RE, Hayashi Y, Nagaya T, Petty KJ, Murata Y, Tunca H, et al. Dominant inheritance of resistance to thyroid hormone not linked to defects in the thyroid hormone receptor alpha or beta genes may be due to a defective cofactor. J Clin Endocrinol Metab 1996;81: 4196-203.

7. Weiss RE, Refetoff S. Resistance to thyroid hormone. Rev Endocr Metab Disord 2000;1:97-108.

8. Kaplan MM, Swartz SL, Larsen PR. Partial peripheral resistance to thyroid hormone. Am J Med 1981;70:1115-21.

9. Fisher DA. Disorders of the thyroid in the newborn and infant. In: Sperling MA, editor. Pediatric Endocrinology. 2nd ed. Philadelphia: WB Saunders 2002;161-85.

10. Refetoff S,Weiss RE, Usala SJ. The syndromes of resistance to thyroid hormone. Endocr Rev 1993;14:348-99.

11. Ercan O. Thyroid hormone resistance. Pediatric Endocrine Reviews 2003;1:191-8.

12. Chatterjee VK. Resistance to thyroid hormone. Horm Res 1997; 48: 43- 6.

13. Kurtoglu S, Covut IE, Kendirci M, Uzum K, Durak AC, Kiris A. Normal thyroid volume of children in Turkey: Pilot study in Kayseri province. IDD Newsletter 1995; 11: 41-2.

14. Beck-Peccoz P, Roncoroni R, Mariotti S, Medri G, Marcocci C, Brabant $G$, et al. Sex hormone-binding globulin measurement in patients with inappropriate secretion of thyrotropin (IST): evidence against selective pituitary thyroid hormone resistance in nonneoplastic IST. J Clin Endocrinol Metab 1990; 71: 19-25.

15. Beck-Peccoz P, Chatterjee VK. The variable clinical phenotype in thyroid hormone resistance syndrome. Thyroid 1994; 4: 225-32. 
16. Weiss RE, Refetoff S. Effect of thyroid hormone on growth. Lessons from the syndrome of resistance to thyroid hormone. Endocrinol Metab Clin North Am 1996; 25: 719-30.

17. Danzi S, Klein I. Thyroid hormone regulatde cardiac gene expression and cardiovascular disease. Tyhroid 2002; 12: 467-72.

18. Brucker-Davis F, Skarulis MC, Grace MB, Benichou J, Hauser P, Wiggs E, et al. Genetic and clinical features of 42 kindreds with resistance to thyroid hormone. The National Institutes of Health Prospective Study. Ann Intern Med 1995; 123: 572-83.
19. Kahaly GJ, Matthews $\mathrm{CH}$,Matthews $\mathrm{CH}$,Mohr-Kahaly S, Richards CA,Chatterjee VKK. Cardiac involvement in thyroid hormone resistance. J Clin Endocrinol Metab 2002; 87: 204-12.

20. Sarne DH, Refetoff S, Rosenfield RL, Farriaux JP. Sex hormonebinding globulin in the diagnosis of peripheral tissue resistance to thyroid hormone: the value of changes after short term triiodothyronine administration. J Clin Endocrinol Metab 1988; 66: 740-6.

21. Sorensen HG, Van der Deure WM, Hansen PS, Peeters RP, Breteler MM, Kyvik KO, et al. Identification and consequences of polymorphisms in the thyroid hormone receptor alpha and beta genes. Thyroid 2008;18:1087-94. 